\title{
SIKAP MEDIA ASING DALAM MENYOROTI KASUS PENISTAAN AGAMA AHOK (Foreign Media Attitude to Highlight Ahok's Blasphemy Case)
}

\author{
Retno Hendrastuti \\ Balai Bahasa Jawa Tengah \\ Jalan Elang Raya 1 Mangunharjo, Tembalang, Semarang, 50272 \\ Telepon 024-76744357, Faksimile 024-76744358 \\ Pos-el: retnohendras@gmail.com \\ (Naskah Diterima Tanggal: 5 Oktober 2019; Direvisi Akhir Tanggal: 4 November 2019; \\ Disetujui Tanggal: 11 November 2019)
}

\begin{abstract}
In 2017, Ahok's Blasphemy Case (ABC) got big attention from foreign mass media. Then, how did the foreign mass media take a position broadcasting it? It is a qualitative descriptive study that aims to describe the attitude and its object of foreign mass media's $A B C$ news texts. The study used lexis and phrases that reflecting attitude as data. The data were collected from $A B C$ Indonesian news texts from three foreign mass media of Deutsche Welle, BBC, and VOA. The data were analyzed with the appraisal approach to finding out their attitude toward $A B C$. The study result showed that there were three kinds of attitudes: positive and negative affects, judgements, and appreciations. The positive affects were to evaluate participants'attitudes who want to create comfort conditions. The negative affects implied fear of ABC as the source of stress and anxiety for Indonesian. Then, the positive personal judgements showed the need for a safe and fair state for $A B C$ and the negative personal judgements showed the stressful aspect. The positive moral judgements were about Ahok's cooperative attitudes. The negative moral judgements were directed to the action of attacking certain people or ideologies. Then, the appreciations focused on evaluating things, people who supported a conducive situation. The negative appreciations were associated with ABC that create chaos situation. However, the domination of positive attitudes were about $A B C$ showed support to finish $A B C$ fairly and peacefully.
\end{abstract}

Keywords: Ahok; foreign mass media; attitude; appraisal theory

\begin{abstract}
Abstrak
Pada 2017, kasus penistaan agama Ahok (KPAA) mendapat perhatian besar dari media massa asing. Lalu, bagaimana media massa asing menyoroti kasus ini? Penelitian ini adalah penelitian deskriptif kualitatif yang bertujuan mendeskripsikan sikap dan objek sikap media massa asing pada teks berita KPAA. Data berupa leksis sikap diambil dari teks berita tiga media massa asing, yaitu Deustche Welle, BBC, dan VOA yang berbahasa Indonesia. Data dianalisis dengan pendekatan appraisal untuk mengetahui sikap mereka terhadap KPAA. Hasil penelitian menemukan tiga jenis sikap, yaitu perasaan, penilaian, dan apresiasi yang bermuatan positif dan negatif terkait KPAA. Perasaan positif ditujukan untuk partisipan yang ingin menciptakan kondisi yang menentramkan. Perasaan negatif mengisyaratkan ketakutan terhadap KPAA sebagai sumber tekanan dan kecemasan bagi bangsa Indonesia. Penilaian personal positif menunjukkan keinginan akan situasi negara aman dan adil dan penilaian personal negatif yang terkait dengan hal-hal yang menciptakan ketegangan. Penilaian moral positif terkait dengan perilaku kooperatif Ahok. Penilaian moral negatif tertuju pada tindakan menyerang orang atau ideologi tertentu. Apresiasi positif fokus mengevaluasi benda atau orang yang mendukung situasi kondusif. Apresiasi negatif dikaitkan dengan situasi gaduh di masyarakat. Dominasi sikap positif menunjukkan dukungan untuk penyelesaian KPAA dengan adil dan damai.
\end{abstract}

Kata kunci: Ahok; media massa asing; sikap; teori appraisal 


\section{PENDAHULUAN}

Pada awal 2017, Indonesia dihebohkan oleh kasus penistaan agama yang melibatkan mantan Gubernur DKI, Basuki Tjahaja Purnama (Ahok). Kasus ini berawal dari munculnya potongan video pidato Ahok di depan para nelayan Kepulauan Seribu di media sosial. Pada potongan video tersebut Ahok terekam berkata, "Jadi, jangan percaya sama orang, kan bisa saja dalam hati kecil Bapak Ibu gak bisa pilih saya, ya- dibohongin pakai surat Almaidah 51 macam-macam itu" (edunews, 2017). Potongan video tersebut kemudian menyebar dengan cepat (viral), yaitu ketika pada 6 Oktober 2016 seorang warganet, Buni Yani, mengunggahnya di facebook. Hal tersebut menyedot perhatian hingga memicu konflik di masyarakat Indonesia. Umat Islam Indonesia keberatan dengan pernyataan Ahok tersebut. Ahok pun dilaporkan atas tuduhan penistaan agama dengan pasal 156 a huruf a dan/atau pasal 156 KUHP.

Sejak saat itu kasus penistaan agama Ahok (selanjutnya disebut KPAA) menjadi berita utama di berbagai media massa. Beberapa media massa asing (selanjutnya disebut MMA) juga menyoroti kasus tersebut. Mereka memberitakan proses bergulirnya kasus ini dengan melaporkan perkembangan kasus tersebut dari awal kemunculannya hingga sampai di pengadilan. Oleh karena itu, sikap mereka terhadap kasus KPAA dapat diteliti untuk melihat keberpihakkan mereka. Karena mengemban peran sebagai sumber informasi, watchdog, mediator, dan advokat, media massa harus netral dan independen (Hidayatulloh dalam Hendrastuti, 2016: 228).

Penelitian ini membahas evaluasi sikap MMA yang terepresentasi melalui penggunaan leksis-leksis yang menunjukkan sikap dalam teks berita kasus penistaan agama Gubernur Provinsi Jakarta Basuki Tjahaja Purnama (Ahok). Sumber data yang digunakan adalah teks berita internet yang diambil dari tiga MMA berbahasa Indonesia, yaitu Deustche Welle, BBC, dan VOA. Pada penelitian ini, teori appraisal digunakan sebagai pendekatan analisis teks berita kasus penistaan agama Gubernur Provinsi Jakarta Basuki Tjahaja Purnama (Ahok) pada media asing yang dipublikasikan lewat internet.

Sebelumnya, penelitian serupa dengan sumber kajian berita dan sikap telah dilakukan Hendrastuti (2016). Penelitian berjudul Penilaian Media Massa Asing terhadap Pilpres 2014: Membedah Teks Berita dengan Teori Appraisal tersebut menunjukkan adanya penilaian kekaguman yang ditujukan kepada yang mendukung pelaksanaan pilpres kondusif, penilaian kecaman kepada yang mengganggu pelaksanaan pilpres kondusif, penghargaan kepada pihak yang loyal dan benar, dan menyalahkan kepada para petinggi negara dan partai yang berperilaku negatif. Selain itu, terlihat adanya kecenderungan penulis atau MMA tersebut mendukung salah satu capres. Kemudian, Nazhira, R., Sinar, S. \& Suriyadi (2016) melakukan penelitian dengan judul "Appraisal Sikap dalam Teks Berita Surat Kabar Nasional". Dalam penelitian tersebut mereka menggambarkan pola sikap pada teks berita dari koran harian Media Indonesia, koran Republika, koran harian Kompas. Hasil penelitian tersebut menunjukkan bahwa (1) pola sikap apraisal di koran harian Media Indonesia dan koran harian Republika, apresiasi ${ }^{\wedge}$ afek $^{\wedge}$ penilaian, dan koran harian Kompas, afek $^{\wedge}$ apresiasi $^{\wedge}$ penilaian. Kecenderungan penggunaan pola sikap leksis negatif menunjukkan penulis koran berita nasional, dan (2) pola cenderungan sikap terjadi karena penulis sering menggunakan fungsi bahasa untuk memengaruhi orang lain dengan memberikan penilaian langsung terhadap suatu hal dan penulis berita koran nasional memiliki kecenderungan menceritakan peristiwa sensitif atau masalah yang menimbulkan keprihatinan terhadap peristiwa-peristiwa yang terjadi di masyarakat. Selain, itu, ada Pusparini, A., Djatmika (2017) yang menggali sistem Appraisal berita eksekusi Duo Bali Nine yang diambil dari laman The Sydney Morning Herald, The Guardian Australia, The Jakarta Globe, dan The Jakarta Post. Penelitian tersebut berjudul 
Analisis Sistem Appraisal Berita Proses Eksekusi Duo Bali Nine (Pendekatan Linguistik Sistemik Fungsional). Hasil menunjukkan bahwa attitude yang ada dalam teks berita mengekspresikan ketertarikan dan ketidakobjektifan jurnalis yang terlihat dari membludaknya penggunaan heterogloss engagement berupa projecting source dalam teks berita yang disajikan. Selain dapat mengamankan posisi penulis serta surat kabar tempat jurnalis bernaung, penggunaan heterogloss engagement juga membuat berita yang dihasilkan lebih akurat. Hal ini dikarenakan penulis menggunakan pendapat orang lain yang dinilainya kompeten dalam peristiwa yang akan diangkat menjadi berita. Graduation tipe raise-force membuat berita yang dihasilkan lebih mengena, ditambah lagi penggunaan force: intensification-isolating membuat berita yang dihasilkan lebih menancap pada pikiran pembaca.

\section{KERANGKA TEORI}

Teori appraisal merupakan salah satu cabang ilmu linguistik fungsional. Teori appraisal menyediakan pendeskripsian atributatribut sebagai ekspresi sikap seseorang ketika dia menulis sebuah teks (Alamsyah, A., Rahmah, W., 2015). Teori appraisal yang dikemukakan oleh White pada 1998 (dalam Nugraheni, 2011: 46) sesuai untuk kajian wacana media (media discourse) karena pandangan holistiknya terhadap bahasa, yaitu bahasa sebagai representasi semiotik sosial. Pendekatan ini dapat menyediakan leksis-leksis sikap yang merupakan penanda evaluasi sikap yang ditujukan kepada partisipan di dalam teks. Partisipan yang dimaksud sesuai dengan topik bahasan, yaitu segala sesuatu yang terkait dengan KPAA. Lebih lanjut, tanda-tanda tersebut dapat digunakan untuk mengetahui sikap MMA terhadap kasus tersebut.

Ada beberapa jenis dan sumber sikap dalam tuturan dan wacana. Salah satu penggagas teori appraisal (Martin, 2004: 322), memaparkan empat jenis fokus sikap dalam wacana, yaitu kata sifat (intensifier), leksis sikap (attitudinal lexis), umpatan (swearing), dan metafora (metaphor). (Martin, J. R., \& White, 2005: 33) menuliskan bahwa appraisal merupakan salah satu dari tiga sumber utama semantik wacana yang menguraikan makna interpersonal.

Selanjutnya, White (2006) menyatakan bahwa sikap merealisasikan tiga aspek yang dapat bermuatan positif atau negatif, yaitu: (1) affect (perasaan), (2) judgement (penilaian), dan (3) appreciation (apresiasi). Martin, J. R., \& Rose (2003) menyatakan bahwa affect digunakan penulis untuk mengekspresikan perasaan suka atau tidak suka. Judgement adalah sikap seseorang terhadap orang lain dan karakter mereka (Martin, J. R., \& White, 2005: 52). Appreciation menerangkan evaluasi terhadap benda, benda yang dibuat, penampilan yang diberikan, termasuk fenomena alam (Martin, J. R., \& White, 2005: 56). Kemudian, evaluasi ini direalisasikan secara langsung dan tidak langsung. Evaluasi langsung dapat dideteksi dari penggunaan bahasa yang lugas menunjukkan perasaan, sedangkan evaluasi tak langsung dapat dilihat melalui penggunaan bahasa yang bersifat metaforis atau makna tak sebenarnya.

\section{METODE}

Penelitian ini bersifat deskriptif kualitatif dengan sumber data teks berita dari media massa asing. Penelitian deskriptif bersandarkan pada data berupa kalimat, bukan data angka atau statistik untuk mendeskripsikan analisis (Moleong, 2000: 18). Metode kualitatif yang digunakan relevan dengan tujuan dalam penelitian ini, yaitu mendeskripsikan aspekaspek sikap berita di internet.

Dalam penelitian ini teknik sampling berdasarkan kriteria yang digunakan untuk menentukan data yang berupa unsur kebahasaan (kata atau frasa) dalam teks berita di internet yang mengandung sikap. Kriteria yang digunakan untuk menentukan data yang bersumber dari teks berita di internet adalah semua unsur kebahasaan yang mengandung sikap dalam teks berita yang menggunakan bahasa Indonesia yang terdapat pada portal berita luar negeri di internet, yaitu, 
Deustche Welle (Belanda), BBC (Inggris), dan VOA (Amerika). Ketiganya dianggap mewakili tiga belahan dunia yang berbeda. Teks berita KPAA dipilih karena isi teksnya sesuai dengan karakteristik data yang diperlukan dalam penelitian sikap, yaitu mengandung unsurunsur kebahasaan dengan muatan sikap. Ada tiga teks berita yang digunakan sebagai bahan kajian. Adapun judul-judul berita dan laman yang memuat berita tersebut adalah (1) Ahok Jadi Tersangka Kasus Dugaan Penodaan Agama (Welle, 2016), (2) Pelaporan Ahok Atas Tuduhan Menghina Agama dan Pemilih (BBC Indonesia, 2016), (3) MUI Diminta Cabut Fatwa Soal Ahok (VOA Indonesia, 2016).

Penelitian ini menggunakan pendekatan teori appraisal untuk menganalisis data. Lebih lanjut, analisis menggunakan empat penahapan, yaitu (1) pengumpulan data, (2) reduksi data, (3) display data, dan (4) pengambilan kesimpulan (Miles \& Huberman dalam Santosa, 2017: 66). Pada tahap pertama dilakukan pemilahan antara data dan yang bukan. Tahap kedua dilakukan dengan mengelompokkan hasil dari analisis tahap pertama, yaitu memilah aspek-aspek sikap perasaan (affect), penilaian (judgement), dan pujian (appreciation). Pada tahap berikutnya analisis dilakukan dengan mengaitkan jenis aspek-aspek sikap dengan objek sikap pada teks berita. Pada tahap terakhir analisis difokuskan untuk mengaitkan jenis dan karakterisik data, sumber data, teori-teori yang digunakan, lokasi penelitian, hasil analisis, dan konteks budaya, sehingga dapat diperoleh gambaran untuk menarik simpulan dalam penelitian ini.

\section{PEMBAHASAN}

Pada penelitian ini terdeteksi penggunaan seluruh aspek evaluasi sikap, baik evaluasi perasaan, penilaian, maupun apresiasi. Evaluasi sikap tersebut terdiri atas dua polaritas, positif atau negatif yang terealisasi dalam kata atau frasa dengan penanda evaluasi sikap. Tabel 1 berikut menunjukkan distribusi temuan evaluasi sikap dalam penelitian ini.
Tabel 1 Jenis-Jenis Sikap

\begin{tabular}{llccc}
\hline No. & Jenis Sikap & Positif & Negatif & å \\
\hline 1. & Perasaan & 8 & 2 & 10 \\
\hline 2. & Penilaian & 32 & 60 & 92 \\
\hline 3. & Apresiasi & 9 & 9 & 18 \\
\hline & Jumlah & 49 & 71 & 120 \\
\hline
\end{tabular}

\section{Evaluasi Perasaan (Affect)}

Evaluasi perasaan merupakan realisasi ekspresi emosional seseorang, sekelompok orang, atau sesuatu yang dianggap seperti orang. Evaluasi ini dapat berupa ungkapan senang, benci, sedih, gembira, dll. Evaluasi perasaan terdiri atas evaluasi perasaan positif dan evaluasi perasaan negatif.

Pada penelitian ini evaluasi perasaan ditemukan dalam sepuluh data. Delapan data merupakan evaluasi perasaan positif, dan dua data adalah evaluasi perasaan negatif. Dalam menentukan evaluasi perasaan, ada leksis-leksis sikap yang menandai evaluasi sikap tersebut. Tabel 2 berikut ini berisi gambaran kelompokkelompok leksis sikap yang menandai evaluasi perasaan dan objek yang ditandainya.

\section{Tabel 2 Penanda dan Objek Evaluasi Perasaan}

\begin{tabular}{ll}
\hline \multicolumn{2}{c}{ Penanda } \\
\hline$+\quad$ mengucapkan terima kasih (6), berterima \\
\\
kasih (7), terima (8), semangat (14), meminta \\
maaf (27), damai (87), damai (96), damai \\
$\quad$ (105) \\
\hline$-\quad$ ujian (30), tekanan (38) \\
\hline \multicolumn{1}{c}{ Objek } \\
\hline$+\quad$ Ahok (6), Ahok (7), Ahok (8), pendukung \\
\\
$\quad$ Ahok (14), Ahok (27), aksi menentang Ahok \\
(87), pilkada (96), pilkada (105) \\
\hline$-\quad$ kasus Ahok (30), publik (38)
\end{tabular}

Tabel 2 menunjukkan evaluasi perasaan dalam penelitian ini. Evaluasi perasaan positif dominan menandai evaluasi perasaan pada penelitian ini. Evaluasi ini ditemukan dalam delapan data. Ekspresi positif ini merealisasikan perasaan partisipan menengenai isi berita. Di 
sini, MMA mengevaluasi sikap partisipan yang ingin menciptakan kondisi yang menentramkan terkait dengan munculnya KPAA. Kurangnya evaluasi perasaan negatif berkaitan dengan keinginan besar untuk menciptakan rasa aman dan damai. Hal ini menimbulkan minimnya perasaan negatif dibandingkan hal-hal yang menimbulkan evaluasi perasaan positif.

Leksis sikap yang berupa frasa verbal mendominasi penanda evaluasi perasaan positif. Ada frasa verbal mengucapkan terima kasih (6), berterima kasih (7), terima, dan meminta maaf (27) menandai evaluasi perasaan. Penandapenanda tersebut menunjukkan rasa penerimaan Ahok atas permasalahan yang ada. Selain itu, ada frasa adjektival semangat (14) dan damai (87, 96, dan 105) yang juga menandai evaluasi perasan positif. Keempat leksis sikap tersebut menyiratkan keinginan bangsa Indonesia akan rasa aman dan damai.

Tabel 2 menunjukkan evaluasi perasaan positif pada penelitian ini yang ditujukan kepada beberapa pihak. Pihak tersebut adalah Ahok (6, 7, 8, 27), pendukung Ahok (14), aksi menentang Ahok (87), pilkada $(96,105)$. Dengan melihat aspek evaluasi perasaan positif dapat terdeteksi bahwa objek evaluasi didominasi dari pihak Ahok. Selain itu, evaluasi perasaan positif ditujukan kepada pihak penentang Ahok dan pelaksanaan pilkada. Evaluasi perasaan ini mendukung harapan untuk pelaksanaan pilkada yang aman dan damai yang melibatkan Ahok sebagai salah satu partisipannya.

Selanjutnya, frasa nominal menandai evaluasi perasaan negatif yang ada di dua data, yaitu ujian (30) dan tekanan (38). Keduanya mengisyaratkan rasa takut dengan munculnya KPAA yang berakibat pada keadaan chaos. Evaluasi perasaan negatif tersebut ditujukan untuk KPAA yang dianggap sebagai sumber tekanan dan kecemasan bagi bangsa Indonesia.

\section{Evaluasi Penilaian (Judgement)}

Pada penelitian ini ditemukan 94 data penilaian (judgement), yang terdiri atas 26 penilaian personal positif atau kekaguman (admiration), 26 penilaian personal negatif atau kecaman (criticism), 6 penilaian moral positif atau penghargaan (praise), dan 34 penilaian moral negatif atau menyalahkan (condemnation). Dominasi penilaian personal menunjukkan bahwa MMA tidak hanya fokus mengevaluasi perilaku-perilaku partisipan yang mematuhi dan melanggar parameter moral dan hukum, tetapi juga berkaitan dengan kenyataan bahwa isu KPPA merupakan bentuk pelanggaran yang berhubungan dengan kelegalan dalam hukum. Berikut uraian dari kedua jenis aspek sikap penilaian tersebut.

\section{a. Penilaian Personal}

Penilaian pribadi merupakan penilaian normatif pada seseorang atau kelompok orang yang tidak berhubungan dengan kelegalan dalam hukum. Penilaian pribadi terdiri atas penilaian positif atau kekaguman (admiration) dan penilaian negatif atau kecaman (criticism). Ada 26 penilaian personal positif dan 26 penilaian personal negatif yang ditemukan pada penelitian ini. Penanda penilaian personal ditandai dengan kata atau frasa yang mengandung sikap dengan penilaian pribadi seseorang. Tabel 3 menunjukkan penanda dan objek yang digunakan dalam penilaian personal.

\section{Tabel 3 Penanda dan Objek Evaluasi Penilaian Personal}

\begin{tabular}{l}
\hline Penanda \\
\hline$+\quad$ baik (9), baik (10), memohon (11), \\
menghormati (12), akan berjuang untuk \\
memenangkan (13), bisa kompromi (41), \\
langkah yang diperhitungkan (42), cerdas \\
(54), kinerja (66), cerdas (68), kinerja (69), \\
dibenarkan (73), pengalaman (75), bersih \\
dari korupsi (76) tegas (77), berpengaruh \\
(81), meminta masyarakat tenang (93), \\
menanggapi dengan bijak (94), bebas \\
SARA (97), tegas (98), sepakat mendukung \\
(104), menegaskan tidak akan mencabut \\
pernyataan (107), sudah sesuai (108), tidak \\
akan mencampuri (109), telah sesuai (110), \\
bijaksana (114)
\end{tabular}


- dilarang (5), berulangkali menuntut (19), menentang (22), protes (24), pesaingnya (28), mencegah memilih (29), kemunduran (32), preseden buruk (34), preseden buruk (35), minoritas (36), didikte (37), lemah (40), kemunduran besar (43), tidak bisa menafsirkan (62), menguras energi (70), 'tidak serta-merta (71), tidak menghiraukan (74), isu (79), menistakan (89), menistakan (90), meningkatkan ketegangan politik (91), konflik horizontal (92), memicu perbedaan (103), polemik (106), tidak bisa memastikan (113), menghina (119)

\begin{tabular}{l}
\hline Objek \\
\hline$+\quad$ contoh (9), proses demokrasi (10), Ahok \\
(11), Ahok (13), pendukung (12), keputusan \\
hukum (41), pemerintah dan polisi (42), \\
orang Jakarta (54), Ahok (66), orang Jakarta \\
(68), Ahok (69), pendapat Sudding (73), \\
Ahok (75, 76, 77), efek (81), iman (93), \\
masyarakat (94), pilkada (97), MUI (98, 107, \\
108, 109, 110), Aliansi Masyarakat Cinta \\
Damai (104), Polri (114) \\
Ahok (5), kelompok Islam (19), aksi (22), \\
aksi (24), lawan politik (28), lawan politik \\
(29), penetapan Ahok sebagai tersangka \\
(32), penetapan Ahok sebagai tersangka \\
(34), penetapan Ahok sebagai tersangka \\
(35), tionghoa (36), hukum (37), penegakan \\
hukum (40), Indonesia (43), Ahok (62), \\
masyarakat (70), polisi (71), 42,5\% pemilih \\
(74), pelecehan Alquran (79), Ahok (89), \\
Ahok (90), kasus Ahok (91), kasus Ahok \\
(92), pernyataan MUI (103), pilkada (106), \\
Bachtiar Nasir (113), Ahok (119)
\end{tabular}

Dari tabel 3 di atas terlihat penggunaan penanda evaluasi penilaian personal positif dari kelompok verbal, adjektiva, dan nominal. Kelompok verbal dominan menandai penilaian personal positif. Ada memohon (11), menghormati (12), akan berjuang untuk memenangkan (13), bisa kompromi (41), dibenarkan (73), berpengaruh (81), meminta masyarakat tenang (93), menanggapi dengan bijak (94), sepakat mendukung (104), menegaskan tidak akan mencabut pernyataan (107), dan tidak akan mencampuri (109). Ketiga belas penanda penilaian personal positif tersebt menunjukkan perilaku-perilaku yang ingin menciptakan situasi kondusif terkait munculnya KPAA.

Kemudian, ada kelompok adjektival yang menandai penilaian personal positif. Penandapenanda tersebut adalah baik $(9,10)$, cerdas $(54$, 68), bersih dari korupsi $(76)$ tegas $(77,98)$, bebas SARA (97), sudah/telah sesuai (108, 110), dan bijaksana (114). Kelompok adjektival tersebut merujuk pada sifat-sifat positif partisipan dalam teks berita KPAA. Begitu juga penanda nominal, seperti langkah yang diperhitungkan (42), kinerja (66, 69), pengalaman (75) juga menunjukkan kualitas positif partisipan.

Selain itu, terdapat juga penanda negatif verbal dominan menandai penilaian personal negatif, seperti dilarang (5), berulangkali menuntut (19), menentang (22), protes (24), mencegah memilih (29), didikte (37), tidak Bachtiar Nasir bisa menafsirkan (62), menguras energi(70), tidakmenghiraukan (74), menistakan (89), menistakan (90), meningkatkan ketegangan politik (91), memicu perbedaan (103), tidak bisa memastikan (113), menghina (119). Kelompok verbal tersebut menunjukkan perilaku negatif Ahok, pendukung, dan penentang Ahok terkait KPPA yang memicu ketegangan bangsa.

Penilaian personal negatif juga ditandai dengan kelompok nominal. Ada pesaing (28), kemunduran (32), preseden buruk (34, 35), kemunduran besar (43), isu (79), konflik horizontal (92), polemik (106). Kelompok nominal tersebut menunjukkan kualitas negatif situasi bangsa karena adanya KPAA. Selain itu, ada kelompok adjektiva yang menandai penilaian personal negatif, seperti minoritas (36), lemah (40), tidak serta-merta (71). Namun, penilaian negatif tersebut menunjukkan kondisi yang tidak menguntungkan kelompok minoritas di Indonesia.

Evaluasi penilaian personal positif pada penelitian ini ditujukan kepada beberapa orang dan aspek. Ada objek contoh (9), proses demokrasi (10), Ahok (11, 13, 66, 69, 75, 76, 77), pendukung (12), keputusan hukum (41), pemerintah dan polisi (42), orang Jakarta (54, 68), pendapat Sudding (73), efek (81), Iman 
(93), masyarakat (94), pilkada (97), MUI (98, 107, 108, 109, 110), Aliansi Masyarakat Cinta Damai (104), Polri (114). Kelompok tersebut merupakan aspek partisipan yang menginginkan situasi negara aman dan adil terkait munculnya KPAA.

Selanjutnya, evaluasi penilaian personal negatif pada penelitian ini ditujukan kepada beberapa orang dan aspek. Ahok (5, 62, 89, 90, 119), kelompok Islam (19), aksi (22, 24), lawan politik $(28,29)$, penetapan Ahok sebagai tersangka (32, 34, 35), Tionghoa (36), hukum (37), penegakan hukum (40), Indonesia (43), masyarakat (70), polisi (71), 42,5\% pemilih (74), pelecehan Alquran (79), kasus Ahok (91, 92), pernyataan MUI(103), pilkada (106), (113). Objek-objek tersebut merupakan hal-hal yang menciptakan ketegangan terkait dengan KPAA.

\section{b. Penilaian Moral}

Evaluasi sikap berupa penilaian moral bersumber dari penilaian yang bersifat normatif atau terkait dengan kelegalan hukum. Ada dua jenis penilaian moral, yaitu penilaian positif atau penghargaan (praise) dan penilaian negatif atau menyalahkan (condemnation). Ada enam penilaian moral positif serta 34 penilaian moral negatif ditemukan pada penelitian ini. Berikut ini tabel 4 yang berisi penanda serta objek penilaian moral.

\section{Tabel 4 Penanda dan Objek Evaluasi Penilaian Moral}

\section{Penanda}

$+\quad$ tidak berniat menghina (50), tidak berniat melecehkan (52), tidak suka mempolitisasi (53), tidak berniat melecehkan (57), tidak suka mempolitisasi (58), tidak ada yang salah (64)

tersangka (3), tersangka (4), tersangka (15), radikal (16), menuduh (17), penistaan agama (18), ditangkap (20), diajukan pengadilan (21), kerusuhan (23), anti-Cina (25), antiKristen (26), kasus (29), tersangka (31), kasus (33), kasus (39), terbukti bersalah melanggar (44), dijatuhi hukuman penjara (45), kasus (46), kasus (47), tuduhan (48),

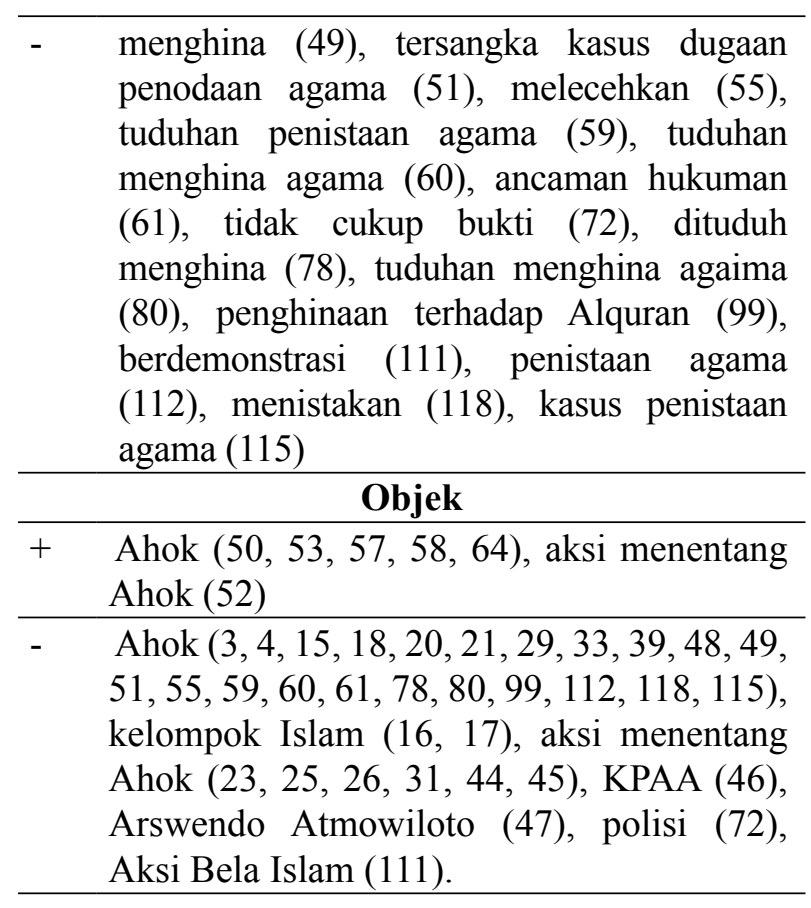

Leksis sikap berbentuk frasa verbal mendominasi penanda penilaian moral positif MMA terhadap partisipan teks berita KPAA. Ada lima data dengan penanda frasa verbal, yaitu tidak berniat menghina (50), tidak berniat melecehkan (52), tidak suka mempolitisasi (53), tidak berniat melecehkan (57), dan tidak suka mempolitisasi (58). Dari enam data tercatat hanya satu data yang berpenanda bukan frasa verbal, yaitu tidak ada yang salah (64). Penggunaan dominan frasa kerja ini ditujukan pada perilaku positif partisipan dalam teks berita MMA tersebut. Keenam penanda tersebut merupakan penilaian positif terhadap perilaku Ahok dalam menghadapi KPA.

Selain itu, penilaian moral negatif dengan penanda kelompok nominal, verbal, dan adjektival juga ditemukan dalam penelitian ini. Penanda nominal dominan pada penilaian tersebut. Ada dua puluh penanda nominal, yaitu tersangka $(3,4,15,31)$, penistaan agama (18), kerusuhan (23), kasus (29, 33, 39, 46, 47), tuduhan (48), tersangka kasus dugaan penodaan agama (51), tuduhan penistaan agama (59), tuduhan menghina agama (60), ancaman hukuman (61), tuduhan menghina agama (80), penghinaan terhadap Alquran (99), penistaan 
agama (112), dan kasus penistaan agama (115). Penanda-penanda tersebut merupakan atribut yang dikenakan pada perilaku yang melawan hukum.

Kemudian, pada penilaian moral negatif ada sepuluh penanda frasa verbal, yaitu menuduh (17), ditangkap (20), diajukan pengadilan (21), terbukti bersalah melanggar (44), dijatuhi hukuman penjara (45), menghina (49), melecehkan (55), dituduh menghina (78), berdemonstrasi (111), dan menistakan (118). Penanda-penanda tersebut terkait dengan perilaku negatif yang berupa tindakan menyerang atau melawan orang lain.

Dari tiga puluh dua data tercatat hanya tiga data penilaian moral negatif yang berpenanda frasa adjektival, yaitu radikal (16), anti-Cina (25), dan anti-Kristen (26). Ketiganya merupakan penanda yang berkaitan dengan faham, yaitu penentangan terhadap faham tertentu.

Seperti terlihat dalam tabel 4, aspek penilaian moral pada penelitian ini ditujukan kepada beberapa pihak. Pihak-pihak yang dimaksud adalah Ahok, penentang Ahok dan polisi. Dengan melihat satu per satu polaritas penilaian dapat terlihat bahwa objek penilaian moral didominasi oleh pihak Ahok yang dihadapkan dalam proses peradilan. Hal ini sesuai dengan topik bahasan pemberitaan yang tak terfokus pada peristiwa-peristiwa dan halhal yang berkaitan dengan KPAA. Penulis atau produsen berita ingin menyampaikan informasi kepada pembaca tentang KPAA di Indonesia dengan memaparkan fenomena terkini yang terkait KPAA.

\section{Evaluasi Apresiasi (Appreciation)}

Ekspresi apresiasi merealisasikan evaluasi yang terfokus pada sifat dan kualitas suatu benda atau yang dibendakan. Pada penelitian ini ditemukan 18 data yang menunjukkan evaluasi apresiasi (appreciation), yang terdiri atas 9 data apresiasi positif dan 9 data apresiasi negatif. Penanda leksis sikap dipergunakan untuk menentukan evaluasi apresiasi tersebut.
Tabel 5 berikut menunjukkan penanda-penanda serta objek evaluasi apresiasi pada teks berita KPAA.

\section{Tabel 5 Penanda dan Objek Evaluasi Apresiasi}

\begin{tabular}{|c|c|}
\hline \multicolumn{2}{|r|}{ Penanda } \\
\hline+ & $\begin{array}{l}\text { terbuka (1), ahli (2), utuh (63), nyata (65), } \\
\text { terbuka (83), terbuka (84), terbuka (85), } \\
\text { persatuan dan kesatuan }(100) \text {, ahli (116) }\end{array}$ \\
\hline & $\begin{array}{l}\text { dipotong (56), pelecehan Al Quran (67), } \\
\text { runtuh (82), isu (86), kontroversi (88), } \\
\text { perbedaan (95), sekelompok golongan } \\
\text { (101), mulai menghangat (102), dipicu (117) }\end{array}$ \\
\hline \multicolumn{2}{|r|}{ Objek } \\
\hline+ & $\begin{array}{l}\text { gelar perkara (1), saksi (2), pidato Ahok } \\
\text { (63), bukti-bukti (65), kampanye }(83,84, \\
\text { 85), masyarakat (100), saksi (116) }\end{array}$ \\
\hline & $\begin{array}{l}\text { pidato Ahok (56), pidato Ahok (67), isu } \\
\text { pelecehan Alquran (82), pelecehan Alquran } \\
\text { (86), pernyataan Ahok (88), pendapat (95), } \\
\text { politisi (101), DKI Jakarta (102), Kasus } \\
\text { Ahok (117) }\end{array}$ \\
\hline
\end{tabular}

Evaluasi apresiasi positif dan negatif yang seimbang menandai evaluasi sikap teks berita MMA. Masing-masing ditemukan sembilan data sikap positif dan negatif. Di sini, penulis atau media massa fokus mengevaluasi karakter partisipan yang memiliki kualitas baik maupun buruk. Partisipan tersebut meliputi perilaku pihak-pihak yang terlibat dalam KPAA, terutama berkaitan dengan pro-kontra munculnya KPAA tersebut.

Dari tabel 5 terlihat bahwa leksis sikap berbentuk frasa adjektival mendominasi penanda evaluasi apresiasi positif. Misalnya, terbuka (1, 83, 84, 85), ahli (2), utuh (63), nyata (65). Selain itu, ada bentuk nominal juga, seperti persatuan dan kesatuan (100), ahli (116). Penanda-penanda tersebut menunjukkan kualitas positif hal-hal yang berkaitan dengan munculnya KPAA.

Selanjutnya, frasa nominal mendominasi penanda evaluasi apresiasi negatif. Ada pelecehan Al Quran (67), runtuh (82), isu (86), kontroversi (88), perbedaan (95), dan 
sekelompok golongan (101). Kemudian, ada frasa verbal, seperti dipotong (56) dan dipicu (117), dan frasa adektival mulai menghangat (102). Frasa-frasa tersebut menggambarkan kualitas negatif dari keadaan yang dipicu oleh KPAA.

Tabel 5 menunjukkan evaluasi apresiasi positif yang ditujukan kepada berbagai objek. Objek-objek yang dimaksud adalah gelar perkara (1), saksi (2), pidato Ahok (63), buktibukti (65), kampanye $(83,84,85)$, masyarakat (100), dan saksi (116). Objek tersebut merupakan fenomena, benda, orang-orang yang mendukung situasi kondusif terkait KPAA.

Objek evaluasi apresiasi negatif pada penelitian ini meliputi beberapa hal. Ada pidato Ahok (56 dan 67), isu pelecehan Alquran (82), pelecehan Alquran (86), pernyataan Ahok (88), pendapat (95), politisi (101), DKI Jakarta (102), dan Kasus Ahok (117). Objek tersebut merupakan penyebab kegaduhan di masyarakat akibat munculnya KPAA.

Berdasarkan temuan-temuan pada penelitian ini, evaluasi sikap terfokus pada tiga aspek sikap dalam appraisal, yaitu perasaan, penilaian, dan penghargaan. Artinya, sikap penulis terhadap KPAA digali dengan melihat penanda serta objek dari ketiga jenis evaluasi sikap yang ditemukan dalam teks berita KPAA. Penanda sikap yang tersurat atau langsung banyak ditemukan dalam penelitian ini. Evaluasi langsung atau eksplisit tersebut dinyatakan penulis dengan menggunakan kata-kata lugas yang berupa kata sifat, kata benda, dan kata kerja yang menunjukkan sikap. Penggunaan metafora yang menunjukkan upaya penghalusan sikap penulis teks tidak ditemukan dalam teks KPAA dalam rangka memberikan evaluasi sikap secara lebih konkret dan langsung.

Objek yang merupakan partisipan yang dievaluasi pada teks KPAA cukup bervariasi. Namun demikian, secara garis besar objek evaluasi sikap dalam teks KPAA dapat dipetakan menjadi dua kubu, yaitu pendukung dan penentang Ahok. Akan tetapi, dapat terlihat bahwa tidak ada dominasi salah satu kubu pada evaluasi sikap positif maupun negatif. Artinya, tidak ada kecenderungan penulis untuk mendukung atau menyalahkan salah satu kubu. Hal ini menunjukkan adanya perhatian dan kepedulian penulis akan kesesuaian dan perdamaian di antara kedua pihak tersebut.

Namun demikian, ketidaknetralan penulis teks berita KPAA tetap ditunjukkan dengan dominannya sikap negatif. Dominasi sikap negatif yang ditemukan dalam teks berita KPAA menunjukkan kecenderungan penulis untuk menyalahkan beberapa partisipan atau objek yang terlibat konflik dalam KPAA ini. Kecenderungan penulis untuk memosisikan diri seperti ini telah diprediksi pada hasil kajian serupa yang menggunakan pendekatan appraisal. Seperti pada penelitian sebelumnya (Hendrastuti (2016); Nazhira, R., Sinar, S. \& Suriyadi (2016); Pusparini, A., Djatmika (2017)) yang menunjukkan bahwa penulis mendukung atau pun menyalahkan beberapa partisipan atau objek di dalam teks berita. Dalam penelitian ini, evaluasi negatif ditujukan kepada orang atau faham yang membuat situasi tidak kondusif untuk menyelesaikan KPAA secara adil dan damai.

\section{PENUTUP}

Ada tiga jenis evaluasi sikap yang ditemukan dalam penelitian ini, yaitu perasaan (affect), penilaian (judgement), dan apresiasi (appreciation) yang bermuatan positif dan negatif. Evaluasi perasaan positif ditujukan untuk partisipan yang ingin menciptakan kondisi yang menentramkan terkait dengan munculnya KPAA. Evaluasi perasaan negatif mengisyaratkan rasa takut dengan munculnya KPAA sebagai sumber tekanan dan kecemasan bagi bangsa Indonesia. Kemudian, evaluasi penilaian personal positif menunjukkan keinginan akan situasi negara aman dan adil terkait KPAA dan penilaian personal negatif yang terkait dengan hal-hal yang menciptakan ketegangan. Penilaian moral positif terkait dengan perilaku Ahok dalam menghadapi KPA. penilaian moral negatif berupa tindakan 
menyerang orang atau faham tertentu. Evaluasi apresiasi positif fokus mengevaluasi benda, orang-orang yang mendukung situasi kondusif terkait KPAA. Evaluasi apresiasi negatif dikaitkan dengan situasi gaduh di masyarakat akibat KPAA. Dominasi sikap positif media massa asing terhadap KPAA menunjukkan dukungan untuk penyelesaian KPAA dengan adil dan damai.

Kajian dengan pendekatan yang sama perlu dilakukan pada teks-teks bidang politik lainnya. Kemudian, seluruh aspek pendekatan appraisal dapat diterapkan untuk menggali sikap penulis secara lebih mendalam. Selain itu, Kajian sikap juga dapat dilakukan pada teksteks bidang lain yang memerlukan eksplorasi ideologi penulis atau masyarakat tertentu.

\section{DAFTAR PUSTAKA}

Alamsyah, A., Rahmah, W., \& I. H. (2015) Sentiment Analysis Based On Appraisal Theory for Marketing Intelligence in Indonesia's Mobile Phone Market. Journal Of Theoretical and Applied Information Technology. $20^{\text {th }}$ December. Volume 82 No. 2 ISSN: 1992-8645. E-ISSN: 1817-3195: 335-340.

BBC Indonesia. (2016, October 7). Pelaporan Ahok atas tuduhan menghina agama dan pemilih. Retrieved from http:// www.bbc.com/indonesia/berita indonesia/2016/10/161007_indonesia_ahok_laporan.

edunews. (2017, April 13). Ini Transkrip Lengkap Ucapan Ahok di Kepulauan Seribu. News. Retrieved from https:// www.edunews.id/news/politik/initranskrip-lengkap-ucapan-ahok-dikepulauan-seribu

Hendrastuti, R. (2016) Penilaian Media Massa Asing terhadap Pilpres 2014: Membedah Teks Berita dengan Teori Appraisal. Sawerigading. Volume 22 No. 1 (Juni), 227-239.
Martin, J. R., \& Rose, D. (2003), Working with Discourse: Meaning Beyond the Clause. London: Continuum.

Martin, J. R., \& White, P. R. R. (2005), The Language of Evaluation Appraisal in English. New York: Palgrave Macmillan.

Martin, J. R. (2004) Mourning: How We Get Aligned. Sage Journals. Volume 15 (2-3 May 1), 321-344.

Moleong, L. J. (2000), Metodologi Penelitian Kualitatif. Bandung: PT Remaja Rosdakarya.

Nazhira, R., Sinar, S., \& Suriyadi. (2016) Appraisal Sikap dalam Teks Berita Surat Kabar Nasional. Jurnal Tutur. Volume 2, No. 1 (Februari), 1-14.

Nugraheni, Y. (2011) Sistem Appraisal pada Teks Iklan Komersial di Tabloid Nova. Jurnal Parole. Volume 4 No. 2 (April), 45-58.

Pusparini, A., Djatmika, R. S. (2017) Analisis Sistem Appraisal Berita Proses Eksekusi Duo Bali Nine (Pendekatan Linguistik Sistemik Fungsional). Jurnal Paramasastra. Volume 4, No. 2 (September), 193-209.

Santosa, R. (2017), Metode Penelitian Kualitatif Kebahasaan. Surakarta: UNS Press.

VOA Indonesia. (2016, October 19). MUI Diminta Cabut Fatwa soal Ahok. Retrieved from https://www. voaindonesia.com/a/mui-diminta-cabutfatwa-soal-ahok-/3557884.html.

Welle, D. (2016, November 11). Ahok Jadi Tersangka Kasus Dugaan Penodaan Agama. Retrieved from http://www. dw.com/ id/ahok-jadi-tersangka-kasusdugaan-penodaan-agama/a-36408788.

White, P. R. (2006). Appraisal: An Overview. Retrieved from http://www.grammatics. com/appraisalguide. 